\title{
The Pinched Cone Conformation of Calix[4]arenes: Noncovalent Rigidification of the Calix[4]arene Skeleton
}

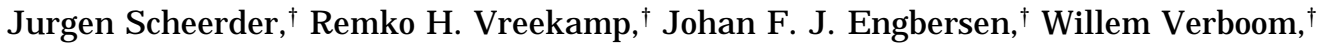 \\ J ohn P. M. van Duynhoven, ${ }^{\ddagger}$ and David N. Reinhoudt*,t \\ Laboratories of Organic Chemistry and Chemical Analysis, University of Twente, P.O. Box 217, \\ 7500 AE Enschede, The Netherlands
}

Received J anuary 21, $1996^{\otimes}$

\begin{abstract}
Calix[4]arenes at the upper rim substituted with two (thio)urea moieties, $\mathbf{2 a}-\mathbf{c}$ and $\mathbf{4}$, or substituted with two acetamido groups, $\mathbf{5}$, adopt a pinched cone conformation in $\mathrm{CDCl}_{3}$ solution. The pinched cone conformation is the result of diametrical, intramolecular hydrogen bonds and was studied by ${ }^{1} \mathrm{H}$ NMR dilution and variable-temperature experiments, NOESY spectroscopy, and FTIR experiments. The pinched cone conformation in these novel calix[4]arenes is stable in $\mathrm{C}_{2} \mathrm{D}_{2} \mathrm{Cl}_{4}$ up to at least $120^{\circ} \mathrm{C}$. The bis(ureido)calix[4]arenes $\mathbf{2 b}, \mathbf{c}$ give a hydrogen-bonded dimer in the pinched cone conformation.
\end{abstract}

\section{Introduction}

Calix[4]arenes ${ }^{1}$ can adopt four extreme conformations in solution, viz. cone, partial cone, 1,2-alternate, and 1,3alternate. The conformational interconversion of calix[4]arenes in solution can be blocked by alkylation of the phenolic oxygens at the lower rim with substituents larger than ethyl. ${ }^{2}$ However, even such tetra-O-alkylated calix[4]arenes still have some flexibility of the skeleton, and computational studies predict that a structure with $\mathrm{C}_{2 v}$ symmetry is more stable than the more symmetrical $\mathrm{C}_{4 v}$ structure. ${ }^{3}$ The $\mathrm{C}_{2 v}$ symmetrical structure has two opposite aromatic rings almost parallel, while the other two adopt a flattened position. ${ }^{4}$ This extreme conformation is called the pinched cone conformation. Crystal structures of calix[4]arenes show that in the solid state most derivatives adopt a pinched cone conformation. ${ }^{5}$ In solution the two conformations having $\mathrm{C}_{2 v}$ symmetry interconvert via a $\mathrm{C}_{4 \mathrm{v}}$ symmetrical cone conformation (Scheme 1). Usually, this interconversion is fast on the NMR time scale, and as a result a time-averaged structure is observed in the ${ }^{1} \mathrm{H}$ NMR spectra, viz. the $\mathrm{C}_{4 \mathrm{v}}$ symmetrical cone conformation.

Regen et al. ${ }^{6}$ reported that the presence of four carboxylic acid groups or four primary carboxamide groups at the upper rim of calix[4]arenes increases the barrier for the interconversion considerably. They suggested that this increase results from intramolecular hydrogen

† Laboratory of Organic Chemistry.

₹ Laboratory of Chemical Analysis.

\& Abstract published in Advance ACS Abstracts, April 15, 1996.

(1) (a) Gutsche, C. D. In Calixarenes Monographs in Supramol ecular Chemistry; Stoddart, J. F., Ed.; The Royal Society of Chemistry: Cambridge, 1989; Vol. 1. (b) Vicens, J ., Böhmer, V., Eds. Calixarenes a Versatile Class of Macrocyclic Compounds; Kluwer Academic Publishers: Dordrecht; 1991. (c) Böhmer, V. Angew. Chem., Int. Ed. Engl. 1995, 34, 713 .

(2) (a) Araki, K.; I wamoto, K.: Shinkai, S.; Matsuda, T. Chem. Lett. 1989, 1747. (b) I wamoto, K.; Araki, K.; Shinkai, S. J . Org. Chem. 1991 $56,4955$.

(3) (a) Grootenhuis, P. D. J .; Kollman, P. A.; Groenen, L. C.; Reinhoudt, D. N.; van Hummel, G. J .; Ugozzoli, F.; Andreetti, G. D. I Am. Chem. Soc. 1990, 112, 4165. (b) Harada, T.; Rudzinski, J. M.; Osawa, E.; Shinkai, S. Tetrahedron Lett. 1993, 49, 5941

(4) (a) Yamada, A.; Murase, T.; Kikukawa, K.; Matsuda, T. Shinkai, S. Chem. Lett. 1990, 455. (b) Yamada, A.; Murase, T.; Kikukawa, K Arimura, T.; Shinkai, S. J. Chem. Soc., Perkin Trans. 2 1991, 793.

(5) Andreetti, G. D.; U gozzoli, F.; Ungaro, R.; Pochini, A. In Inclusion Compounds; Atwood, J. L., Davies, J. E. D., MacNicol, D. D., Eds.; Oxford University Press: Oxford 1991; Vol. 4, p 64.

(6) Conner, M.; J anout, V.; Regen, S. L. J . Am. Chem. Soc. 1991, $113,9670$. bonding between the two opposite carboxylic acid or primary carboxamide groups. Arduini et al. ${ }^{7}$ reported a calix[4]arene substituted with two carboxylic acid groups at the upper rim that forms in solution hydrogen-bonded dimers in which the calix[4]arenes adopt a pinched cone conformation. Recently, Shinkai et al. ${ }^{8}$ showed that the interconversion between the pinched cone conformations can be blocked by the interaction of the aromatic rings with $\mathrm{Ag}^{+}$.

The pinched cone conformation may influence the properties of calix[4]arene-based receptors. Hence, it is important to understand the nature of the pinched cone conformation. The effect of the pinched cone conformation on the result of an alkylation reaction was reported by Timmerman et al. ${ }^{9}$ Reaction of a tetra-O-alkylated calix[4]arene derivative functionalized at the upper rim with two chloroacetamide groups in the diametrical $(1,3)$ positions with tetrahydroxyresorcin[4]arene occurs at the 1 and 2 positions of the tetrahydroxyresorcin[4]arene and not at the 1 and 3 positions. ${ }^{9}$

In this paper, we report diametrically functionalized calix[4]arenes which adopt the pinched cone conformation in solution and provide evidence that this conformation results from intramolecular hydrogen bonding. In this way the calix[4]arene skel eton is rigidified via noncovalent interactions. ${ }^{10}$

\section{Results and Discussion}

Synthesis. Starting from the 1,3-diaminocalix[4]arene tetraethyl ester $\mathbf{1},{ }^{11}$ the bis(ureido) derivatives $\mathbf{2 a}-\mathbf{c}$ (Chart 1) were prepared in $36-44 \%$ yield by the

(7) Arduini, A.; Fabbi, M.; Mirone, L.; Pochini, A.; Secchi, A.; Ungaro, R. J . Org. Chem. 1995, 69, 1454

(8) I keda, A.; Tsuzuki, K.; Shinkai, S. J . Chem. Soc., Perkin Trans. 2 1994, 2073

(9) Timmerman, P.; Nierop, K. G. A.; Brinks, E. A.; Verboom, W.; van Veggel, F. C. J . M.; van Hoorn, W. P.; Reinhoudt, D. N. Chem. J . Eur. 1995, 1, 132.

(10) For recent examples of covalent rigidification of the calix[4]arene skeleton, see: (a) Arduini, A.; Fanni, S.; Manfredi, G.; Pochini, A.; Ungaro, R.; Sicuri, A. R.; Ugozzoli, F. J . Org. Chem. 1995, 60, 1448. (b) Arduini, A.; Fanni, S.; Pochini, A.; Sicuri, A. R.; Ungaro, R. Tetrahedron 1995, 51,7951. For stabilization of the pinched cone conformation via upper rim bridging, see: (c) Goldmann, H.; Vögt, W.; Paulus, E.; Böhmer, V. J . Am. Chem. Soc. 1988, 110, 6811. (d) Böhmer, V.: Vögt, W.: Goldmann, H.; McKervey, A. M.; Owens, M.; Cremin, S.; Collins, E. M. J . Org. Chem. 1990, 55, 2569 .

(11) Rudkevich, D. M.; Verboom, W.; Reinhoudt, D. N.J . Org. Chem. 1994, 59, 3683. 


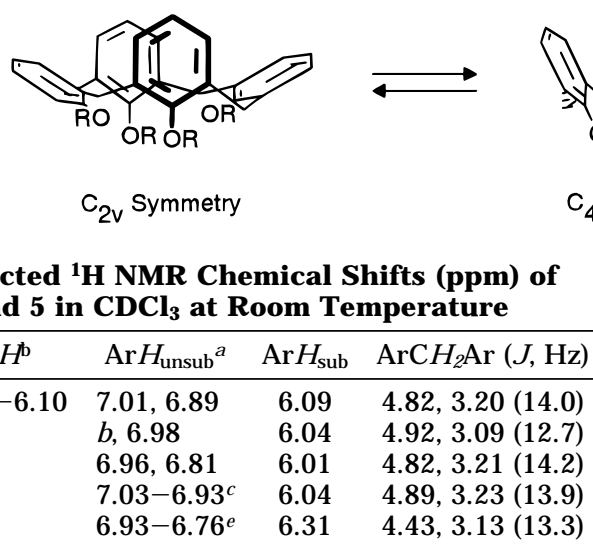

a The first $\delta$ value represents a doublet, the second a triplet. b Signal coincides with the signals for the aromatic hydrogens of the calix[4]arene skeleton and of the phenyl substituent at the urea moiety. ${ }^{\mathrm{C}}$ Broad signal. ${ }^{\mathrm{d}} \leq 5 \%$ of a minor conformer is present. e Multiplet.

\section{Chart 1}
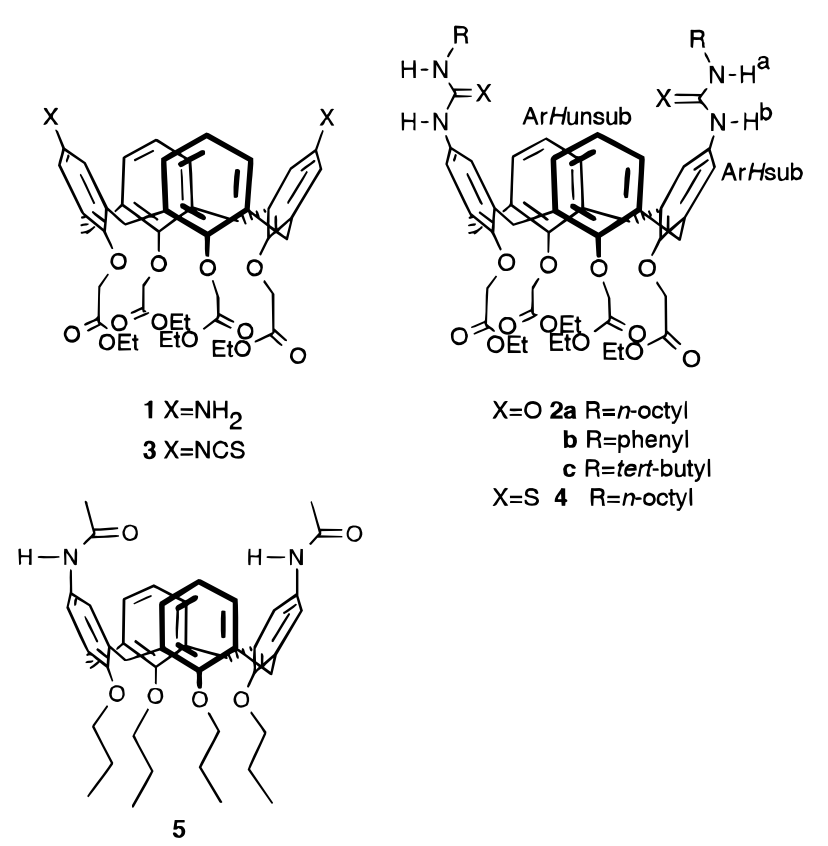

addition of 2 equiv of the appropriate isocyanates to a solution of 1,3-diaminocalix[4]arene $\mathbf{1}$ in $\mathrm{CHCl}_{3}$. In addition, 1,3-diaminocalix[4]arene $\mathbf{1}$ was treated with thiophosgene ${ }^{12}$ to give the 1,3-diisothiocyanatocalix[4]arene 3 in $87 \%$ yield. Subsequent addition of n-octylamine gave the bis(n-octylthioureido)calix[4]arene $\mathbf{4}$ in $68 \%$ yield. The characteristic ${ }^{1} \mathrm{H}$ NMR data of the bis((thio)ureido)calix[4]arenes $\mathbf{2 a}-\mathbf{c}$ and $\mathbf{4}$ are summarized in Table 1 . In addition, bis(acetamido)calix[4]arene $\mathbf{5}^{13}$ has been included in this study.

The four aromatic hydrogens of the substituted aromatic rings of the calix[4]arene skeleton (ArHsub) give one signal in the ${ }^{1} \mathrm{H}$ NMR spectrum of bis((thio)ureido)cal ix[4]arenes $\mathbf{2 a}-\mathbf{c}$ and $\mathbf{4}$. The six aromatic hydrogens of the unsubstituted aromatic rings of the calix[4]arene skeleton (ArHunsub) give a doublet and triplet in the ${ }^{1 \mathrm{H}}$

(12) Drobnica, L.; Kristián, P.; Augustín, J . in The Chemistry of Cyanates and their Thio Derivatives; Patai, S., Ed.; J ohn Wiley \& Sons: New York, 1977; Part 2, p 1032.

(13) Verboom, W.; Bodewes, P.; van Essen, G.; Timmerman, P.; van Hummel, G. J .; Harkema, S.; Reinhoudt, D. N. Tetrahedron 1995, 51, 449.
Scheme 1

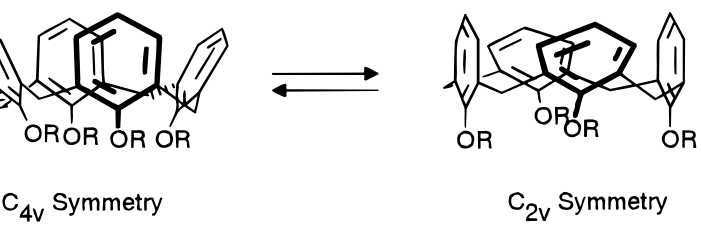

NMR spectrum. The signals at 5.08 and $6.50 \mathrm{ppm}$ in the ${ }^{1} \mathrm{H}$ NMR spectra of bis(n-octyl(thio)ureido)calix[4]arenes $\mathbf{2 a}$ and $\mathbf{4}$, respectively, are triplets and can be assigned to the $\mathrm{NH}^{\mathrm{a}}$ hydrogens which couple with the neighboring methylene hydrogens of the n-octyl groups. Consequently, for 2a, the broad signal at 6.04-6.10 ppm can be assigned to the $\mathrm{NH}^{\mathrm{b}}$ hydrogens. Along this line, for bis(tert-butylureido)calix[4]arene $\mathbf{2 c}$ the most upfield positioned signal (5.09 ppm) is assigned to $\mathrm{NH}^{\mathrm{a}}$ and the most downfield positioned signal $(6.27 \mathrm{ppm})$ to the $\mathrm{NH}^{\mathrm{b}}$ hydrogens. The assignment of the urea hydrogens of bis(phenylureido)calix[4]arene $\mathbf{2 b}$ is based on NOESY spectroscopy. On the basis of NOE connectivities between the signal for ArHsub and the signal at $6.63 \mathrm{ppm}$ this resonance is assigned to $\mathrm{NH}^{\mathrm{b}}$.

Conformational Behavior. The ${ }^{1} \mathrm{H}$ NMR spectra of the bis((thio)ureido)calix[4]arenes $\mathbf{2 a}-\mathbf{c}$ and $\mathbf{4}$ show two different signals for the aromatic hydrogens of the calix[4]arene, as can be expected on the basis of the diametrical substitution pattern. However, the signals for the aromatic hydrogens of the substituted aromatic rings (ArHsub) are at unusually high field (Table 1). In addition, the ${ }^{1 H}$ NMR spectrum of bis(n-octylureido)calix[4]arene 2a shows two signals for the $\mathrm{NH}^{\mathrm{a}} \mathrm{CH}_{2}$ hydrogens. Bis(acetamido)calix[4]arene $\mathbf{5}$ exhibits a spectroscopic behavior similar to that of calix[4]arenes $\mathbf{2}$ and $\mathbf{4}$ with the signal for the aromatic hydrogens of the substituted aromatic rings at $6.31 \mathrm{ppm}$.

The distances between the equatorial calix[4]arene bridging methylene hydrogens $\left(\mathrm{H}_{\text {eq }}\right)$ and the two adjacent aromatic hydrogens $\left(\mathrm{H}_{1}\right.$ and $\mathrm{H}_{2}$, Chart 2) provide information about the structure of the calix[4]arene skel eton in solution. When the calix[4]arene skeleton adopts a (time-averaged) $\mathrm{C}_{4 \mathrm{v}}$ symmetrical cone conformation these distances are equal, but they differ substantially when the calix[4]arene skeleton adopts a structure that deviates from the $\mathrm{C}_{4 \mathrm{v}}$ symmetrical cone conformation. The distances between the equatorial calix[4]arene bridging methylene hydrogens and the two adjacent aromatic hydrogens were determined by NOESY ${ }^{14-16}$ spectroscopy. The distances (Table 2) were determined using the initial rate approximation ${ }^{17}$ in which the distance of $1.79 \AA$

(14) J eener, J .; Meier, B. H.; Bachmann, P.; Ernst, R. R. J . Chem. Phys. 1979, 71, 4546

(15) Neuhaus, D.; Williamson, M. P. The Nuclear Overhauser Effect in Structural and Conformational Analysis; VCH Publishers: Cambridge, U.K., 1989. 
Table 2. Calculated Distances $(\AA)$ between the $H_{\mathrm{eq}}{ }^{\mathrm{a}}$ and the Adjacent Aromatic Hydrogens in $2 a-c, 4$, and $5^{b, c}$

\begin{tabular}{cccccc}
\hline calix & $\mathbf{2 a}$ & $\mathbf{2 b}$ & $\mathbf{2 c}$ & $\mathbf{4}^{\mathrm{d}}$ & $\mathbf{5}$ \\
\hline $\mathrm{H}_{1} \mathrm{e}^{\mathrm{e}}$ & 2.3 & 2.5 & $\mathrm{f}$ & 2.5 & 2.5 \\
$\mathrm{H}_{2} \mathrm{e}$ & 3.2 & 3.0 & $\mathrm{f}$ & 3.1 & 2.8
\end{tabular}

${ }^{a} \mathrm{H}_{\text {eq }}$ are the equatorial calix[4]arene bridging methylene hydrogens. ${ }^{b} \mathrm{CDCl}_{3}, 303 \mathrm{~K}$. ${ }^{c} \pm 0.2 \AA$. d Determined at $218 \mathrm{~K}$. e For $\mathrm{H}_{1}$ and $\mathrm{H}_{2}$ see Chart 2. ${ }^{\mathrm{f}} \mathrm{N}$ ot determined quantitatively, but ROESY spectroscopy clearly indicates a longer distance (factor 1.2) for $\mathrm{H}_{2}$ in comparison to $\mathrm{H}_{1}$.

\section{Chart 3. Pinched Cone Conformation of $2 a$ and 4 (Left) and the Proposed Hydrogen-Bonded Dimer Formed by 2b,c (Right)}
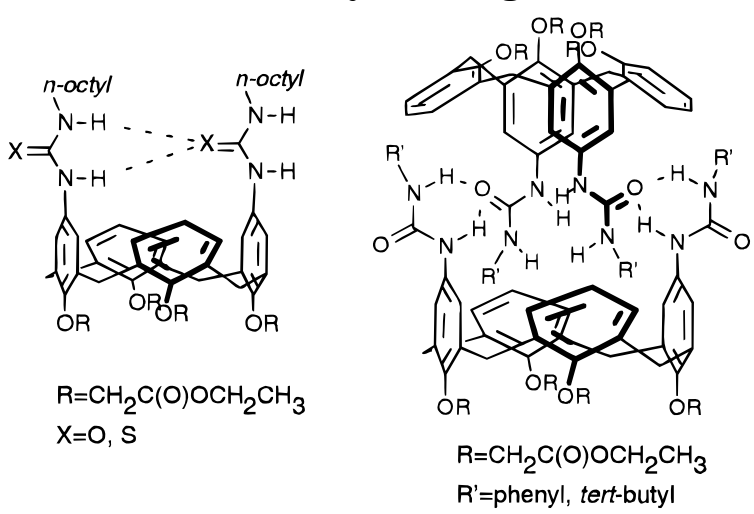

between the equatorial and axial bridging methylene hydrogen atoms (Chart 2) was used as a reference.

The difference between the distances of equatorial methylene hydrogens to the two adjacent aromatic hydrogens indicates that the bis((thio)ureido)calix[4]arenes $\mathbf{2} \mathbf{a}-\mathbf{c}, \mathbf{4}$, and $\mathbf{5}$ adopt a pinched cone conformation in $\mathrm{CDCl}_{3}$ solution at room temperature. ${ }^{18}$

The pinched cone conformation in the bis((thio)ureido)calix[4]arenes $\mathbf{2 a}-\mathbf{c}$ and $\mathbf{4}$ explains the upfield shift of the aromatic hydrogens of the substituted aromatic rings $\left(\mathrm{H}_{1}\right)$. The hydrogen bonding between the urea moieties (Chart 3, vide infra) brings the two opposite aromatic rings in close proximity with the result that the aromatic hydrogens of these aromatic rings are shielded.

In bis(ureido)calix[4]arenes $\mathbf{2 a}-\mathbf{c}$ and $\mathbf{4}$ the distance between $\mathrm{H}_{\mathrm{eq}}$ and $\mathrm{H}_{2}$ is larger than the distance between $\mathrm{H}_{\text {eq }}$ and $\mathrm{H}_{1}$ (Chart 2), indicating that the aromatic rings functionalized with the (thio)urea moieties are oriented toward each other and that the other two aromatic rings are flattened. The pinched cone conformation in $\mathbf{2 a}$ and 4 is depicted in Chart 3.

The NOESY spectrum of bis(phenylureido)calix[4]arene $\mathbf{2 b}$ shows NOE connectivities between the signals for the aromatic hydrogens of the phenyl substituents

(16) (a) For an early study of the conformations of calix[4]arenes in solution using NOESY spectroscopy, see: Alfieri, C.; Dradi, E.; Pochini, A.; Ungaro, R. Gazz. Chim. Ital. 1989, 119, 335. (b) Exchange connectivities in the NOESY spectrum were identified by ROESY experiments where ROE and exchange connectivities have opposite signs. For an introduction to ROESY spectroscopy, see: Bothner-By, A. A.; Stephens, R. L.; Lee, L.; Warren, C. D.; J eanloz, R. W. J . Am. Chem. Soc. 1984, 106, 811.

(17) Ernst, R. R.; Bodenhausen, G.; Wokaun, A. Principles of Nuclear Magnetization Resonance in One and Two Dimensions; Breslow, R. Goodenough, J. B., Halpern, J., Rowlinson, D., Eds.; International Series of Monographs on Chemistry; Clarendon Press: Oxford, 1987; Vol. 14, pp 490-538.

(18) The distances between the equatorial bridging methylene hydrogens $\left(\mathrm{H}_{\mathrm{eq}}\right)$ and the two adjacent aromatic hydrogens $(\mathrm{ArH})$ of tetrakis(n-octylureido)calix[4]arene, which adopts a $\mathrm{C}_{4 v}$ symmetrical cone conformation in $\mathrm{CDCl}_{3}$ solution, are equal, $2.7 \AA$. Scheerder, J Ph. D. Thesis, University of Twente, 1995.
Table 3. Presence of Intermolecular NOE Connectivities and the Cross Relaxation Constants $\left(\sigma, \mathbf{s}^{-1}\right)$ Observed for the Methylene Bridging Hydrogens in $2 a-c$ and $4^{a}$

\begin{tabular}{lllll}
\hline \multicolumn{1}{c}{ calix } & $\mathbf{2 a}$ & $\mathbf{2 b}$ & $\mathbf{2 c}$ & $\mathbf{4}$ \\
\hline inter NOE & no & yes & yes & no \\
$\sigma$ & +0.12 & -1.8 & -0.6 & +0.3
\end{tabular}

a $\mathrm{CDCl}_{3}, 303 \mathrm{~K}$.

and the aromatic hydrogens of the calix[4]arene skel eton $\left(\mathrm{H}_{1}\right.$ and $\mathrm{H}_{2}$, Chart 2), while the NOE SY spectrum of bis(tert-butylureido)calix[4]arene $\mathbf{2 c}$ shows an NOE connectivity between the signals for the hydrogens of the tert-butyl groups and the aromatic hydrogens $\mathrm{H}_{1}$ and $\mathrm{H}_{2}$. These connectivities cannot result from through-space interactions within a single molecule since in the same molecule these hydrogens are not close enough. ${ }^{19}$ Consequently, these NOE connectivities must result from intermolecular interactions (Table 3).

Furthermore, the sign of the NOE connectivities in the NOESY spectra of calix[4]arenes $\mathbf{2 b}$ and $\mathbf{2 c}$ is positive (i.e, negative cross relaxation constants), suggesting that slow tumbling entities, i.e, with increased molecular mass ( $\left.\geq 2000 \mathrm{~g} \cdot \mathrm{mol}^{-1}\right)$ are present. ${ }^{20} \mathrm{Bis}(\mathrm{n}$-octylureido)calix[4]arene $\mathbf{2 a}$ and bis(n-octylthioureido)calix[4]arene 4 do not show any indication of association because no intermolecular NOE connectivities are observed between the hydrogens of the n-octyl substituent at the urea moieties and the aromatic hydrogens $\mathrm{H}_{1}$ and $\mathrm{H}_{2}$.

Using the initial rate approximation, ${ }^{17}$ cross relaxation constants $(\sigma)$ between the bridging methylene hydrogens were determined (Table 3). ${ }^{21}$ The $\sigma$ values are an indication for the degree of aggregation of the two atoms involved. ${ }^{15}$ The negative $\sigma$ values for $\mathbf{2 b}$,c suggest aggregation and are in agreement with the presence of intermolecular NOE connectivities. The positive $\sigma$ values for $\mathbf{2 a}$ and $\mathbf{4}$ suggest that no aggregation occurs and support the absence of intermolecular NOE connectivities.

The intermolecular NOE connectivities may result from a dimeric hydrogen-bonded structure formed by two bis(ureido)calix[4]arenes in the pinched cone conformation as depicted in Chart 3. Such a structure brings the substituents at the urea moieties close to the aromatic hydrogens of the substituted aromatic rings $(\mathrm{ArH})$, and the increased molecular mass of this dimer can explain the negative $\sigma$ values.

The proposed hydrogen-bonded dimer shows that of the eight urea hydrogens present in the dimer four urea hydrogens are involved in intermolecular hydrogen bonding and four urea hydrogens are not involved in hydrogen bonding which is supported by concentration dependent FTIR measurements (vide infra).

In the case of bis(acetamido)calix[4]arene $5^{\mathrm{l}} \mathrm{H}$ NMR dilution experiments show an upfield shift of the amide hydrogens, but this shift is not accompanied by a significant downfield shift of the aromatic hydrogens of the substituted aromatic rings of $\mathbf{5}$. An association constant of $3.8 \mathrm{M}^{-1}$ was determined by a dilution experi-

(19) NOE connectivities can be observed when the through-space distance between two hydrogens is smaller than $4.5 \AA .{ }^{15}$

(20) Positive NOE connectivities $\left(\omega \tau_{c}>1\right)$ are observed for large molecules, viscous solution, low temperature, or strong magnetic fields. Negative NOE connectivities $\left(\omega \tau_{\mathrm{c}}<1\right)$ are observed for small molecules, nonviscous solutions, high temperature, and weak magnetic fields. See ref 15.

(21) Isotropic tumbling and pure dipole-dipole relaxation is assumed. Wüttrich, K. NMR of Proteins and Nucleic Acids; J ohn Wiley \& Sons, Inc.: New York, 1986; Chapter 6. 
ment ${ }^{22}$ which is comparable to the oligomerization of $\mathrm{N}$-alkylated linear carboxamides. ${ }^{23}$ V.P.O. molecular weight determinations ${ }^{24}$ in $\mathrm{CDCl}_{3}$ gave a molecular mass of $845 \pm 80 \mathrm{~g} \cdot \mathrm{mol}^{-1}$ which is slightly higher than the calculated molecular mass of the monomer $\left(707 \mathrm{~g} \cdot \mathrm{mol}^{-1}\right)$. The slight deviation may result from weak intermolecular association. ${ }^{25}$

The pinched cone conformation in bis(ureido)calix[4]arene $\mathbf{2 a}$, and on the basis of its analogy to $\mathbf{2 a}$ probably also in bis(thioureido)calix[4]arene $\mathbf{4}$, is the result of intramolecular hydrogen bonding between the two opposite (thio)urea moieties (Chart 3), whereas the pinched cone conformation of $\mathbf{2 b}, \mathbf{c}$ results from hydrogen bonding between the two monomers in the dimer (Chart 3). The role of hydrogen bonding in the formation of the pinched cone conformations is supported by the ${ }^{1} \mathrm{H}$ NMR spectra of the bis(ureido)calix[4]arenes $\mathbf{2 a}-\mathbf{c}$ in DMSO- $\mathbf{d}_{6}$ which show the signal for the aromatic hydrogens of the substituted aromatic rings more downfield than in the ${ }^{1} \mathrm{H}$ NMR spectra in $\mathrm{CDCl}_{3}$. Due to the breaking of the hydrogen bonding in this solvent $\mathbf{2} \mathbf{a}-\mathbf{c}$ adopt a timeaveraged $\mathrm{C}_{4 \mathrm{v}}$ symmetrical cone conformation. Bis(acetamido)calix[4]arene $\mathbf{5}$ shows a similar behavior. In the ${ }^{1} \mathrm{H}$ NMR spectrum in $\mathrm{CDCl}_{3}$ the signal for the aromatic hydrogens of the substituted aromatic rings is positioned at $6.31 \mathrm{ppm}$ while in DMSO- $\mathrm{d}_{6}$ this signal is present at $7.04 \mathrm{ppm}$. The opposite is observed for the aromatic hydrogens of the unsubstituted aromatic rings: $6.93-6.76 \mathrm{ppm}$ in $\mathrm{CDCl}_{3}$ versus $6.41 \mathrm{ppm}$ in DMSO- $\mathrm{d}_{6}$. The pinching in $\mathrm{CDCl}_{3}$ is also expressed by the chemical shift of the $\mathrm{OCH}_{2}$ hydrogens, which are 0.26 ppm apart in $\mathrm{CDCl}_{3}$, while in DMSO- $\mathrm{d}_{6}$ the difference is 0.11 ppm. $^{26}$

The nature of the hydrogen bonds was studied with FTIR spectroscopy. Concentration-dependent FTIR measurements of bis(ureido)calix[4]arenes $\mathbf{2 a}-\mathbf{c}$ in $\mathrm{CDCl}_{3}(1-$ $20 \mathrm{mM}$ ) reveal a broad, concentration-independent $\mathrm{NH}$ stretching band at $3336 \mathrm{~cm}^{-1}$, attributed to intramolecular $\mathbf{N H}---\mathrm{O}=\mathrm{C}$ hydrogen bonds in monomeric $\mathbf{2 a}$ or intermolecular $\mathbf{N H}---\mathrm{O}=\mathrm{C}$ hydrogen bonds in dimeric $\mathbf{2 b}$ and $\mathbf{2 c}$. In addition, a weak, sharp $\mathrm{NH}$ stretching band at $3420 \mathrm{~cm}^{-1}$, attributed to non-hydrogen-bonded $\mathrm{NH}$ stretch, was observed for $\mathbf{2 a}-\mathbf{c}$.

Variabletemperature ${ }^{1} \mathrm{H}$ NMR experiments with $\mathbf{2 a}-\mathbf{c}$ and 4 in a range of -60 to $+120^{\circ} \mathrm{C}$ and with 5 in a range of -60 to $+145^{\circ} \mathrm{C}$ show no interconversion between the pinched cone conformation and the $\mathrm{C}_{4 \mathrm{v}}$ symmetrical cone conformation.

Molecular Modeling. Molecular modeling (quanta/ $\mathrm{CHARMm})^{27}$ of the pinched cone conformation of bis(noctylureido)cal ix[4]arene $\mathbf{2 a}$ in vacuo shows a bifurcated $\mathrm{NH}--\mathrm{O}=\mathrm{C}$ hydrogen bond $\left(\mathrm{r}\left(\mathrm{H}^{\left.\mathrm{b}_{-}--\mathrm{O}\right)}=1.797\right.\right.$ and

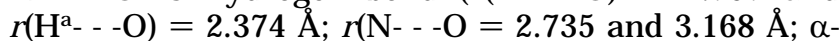
$\left(\mathrm{NH}^{\mathrm{b}}-\mathrm{-}_{-\mathrm{O}}=153.6^{\circ}\right.$ and $\alpha\left(\mathrm{NH}^{\mathrm{a}}-\mathrm{-}_{-\mathrm{O}}\right)=135.9^{\circ}$ ) (Figure 1). ${ }^{28,29}$ Hydrogen bonds can be described using three parameters, $\alpha(\mathrm{NH}---\mathrm{O}), r\left(\mathrm{H}-\mathrm{-}_{-\mathrm{O}}\right)$, and $\mathrm{r}\left(\mathrm{N}-\mathrm{-}_{-\mathrm{O}}\right.$ ) (Figure

(22) In the ${ }^{1 \mathrm{H}}$ NMR dilution experiments the $\mathrm{NH}$ signal was used as a probe. The data were treated using the linear regression method as described: Horman, I.; Dreux, B. Helv. Chim. Acta 1984, 67, 754.

(23) Krikorian, S. E. J . Phys. Chem. 1982, 86, 1875.

(24) When the V.P.O. data were treated according to the method of Schrier the best fit was found for the model assuming oligomerization see: Schrier, E. E. J. Chem. Ed. 1986, 55, 176.

(25) ${ }^{1} \mathrm{H}$ NMR studies and MO calculations suggest that formation of higher linear aggregates is preferred over dimerization; see: Graham, L. L.; Chang, Y. C. J . Phys. Chem. 1971, 75, 776.

(26) The behavior in acetonitrile- $d_{3}$ and acetone- $d_{6}$ resembles the behavior in DMSO- $d_{6}$ concerning the shifts of the aromatic hydrogens.

(27) Brooks, B. R.; Bruccoleri, R. E.; Olafson, B. D.; States, D. J .; Swaminthan, S.; Karplus, M. J . Comput. Chem. 1983, 4, 187.

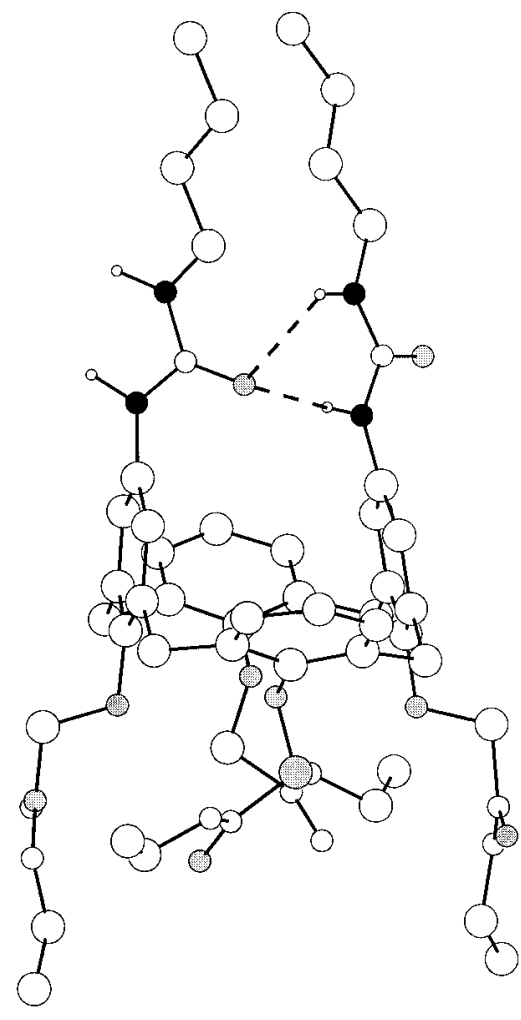

Figure 1. Energy-minimized structure of the pinched cone conformation of $\mathbf{2 a}$. Nonpolar hydrogen atoms are omitted. Nitrogen atoms are colored black, and carbonyl atoms are colored gray.

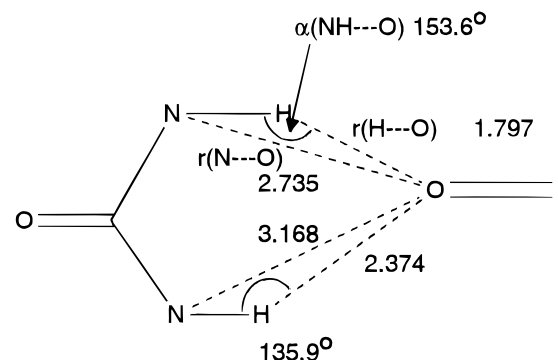

Figure 2. Geometry of the bifurcated hydrogen bonding motif in 2a. Distances are given in $\AA$.

2), ${ }^{30}$ in which $\alpha(\mathrm{NH}---\mathrm{O})$ is the hydrogen bond angle that varies between 90 and $180^{\circ}, r\left(\mathrm{~N}-\right.$ - $\left.^{-O}\right)$ is the hydrogen atom-hydrogen bond acceptor-atom distance and is generally smaller than $3 \AA$, and $r\left(\mathrm{~N}-\mathrm{-}_{\mathrm{-O}} \mathrm{O}\right)$ is the hydrogen bond donor atom-hydrogen bond acceptor atom distance and generally is between 2.4 and $3.2 \AA .{ }^{31}$ The values obtained with molecular modeling are in accordance with these values. The average values for the parameters for $\mathrm{NH}-\mathrm{-}-\mathrm{O}=\mathrm{C}$ hydrogen bonds have been determined on the basis of a survey of the Cambridge Structural Database (CSD) by Taylor et al.30,32 These average values for intramolecular hydrogen bonds are $\alpha\left(\mathrm{NH}-\mathrm{-O}^{-\mathrm{O}}\right)=146.8^{\circ}$ and $\mathrm{r}(\mathrm{H}-\mathrm{-}-\mathrm{O})=2.004 \AA$.

(28) (a) Etter, M. C. Acc. Chem. Res. 1990, 23, 121. (b) Etter, M. C.; Panuto, T. W. J . Am. Chem. Soc. 1988, 110, 5896.

(29) The two aromatic rings are almost parallel and their closest distance is $4.51 \AA$, indicating that $\pi-\pi$ stacking is unlikely to contribute to the stability of the pinched cone conformation. Hunter, C. A.; Sanders, J. K. M. J . Am. Chem. Soc. 1990, 112, 5525.

(30) Taylor, R.; Kennard, O.; Versichel, W. Acta Crystallogr. 1984, B40, 280.

(31) Picard, B.; Baudoux, G.; Durant, F. Acta Crystallogr. 1995, B51, 103. 
The values obtained from the mol ecular modeling are in reasonable agreement with the average values derived from the CSD. One of the hydrogen bonds of the bifurcated hydrogen bonding motif in $\mathbf{2 a}$ as depicted in Figure 2 has a smaller $\alpha\left(\mathrm{NH}-\mathrm{-}^{-} \mathrm{O}\right)$ angle and a larger $\mathrm{r}(\mathrm{H}-\mathrm{-}-\mathrm{O})$ distance, indicating that this hydrogen bond is weaker than an averaged bifurcated hydrogen bond. The other hydrogen bond has a larger $\alpha\left(\mathrm{NH}-\mathrm{-}_{-\mathrm{O}}\right)$ angle and a shorter $\mathrm{r}\left(\mathrm{H}-\mathrm{-}_{-\mathrm{O}}\right)$ distance, indicating that this hydrogen bond is stronger than an averaged bifurcated hydrogen bond. The values for $\alpha(\mathrm{NH}--\mathrm{O}), \mathrm{r}\left(\mathrm{N}-\mathrm{-}^{-\mathrm{O}}\right)$, and $\mathrm{r}(\mathrm{H}-\mathrm{-}-\mathrm{O})$ are in agreement with the values obtained from crystal structures of $\mathrm{N}, \mathrm{N}^{\prime}$-diarylated derivatives. ${ }^{33}$

\section{Conclusions}

Calix[4]arenes functionalized at the upper rim with two (thio)ureido moieties adopt a pinched cone conformation in $\mathrm{CDCl}_{3}$ due to hydrogen bonding between the urea hydrogens and the urea carbonyl atoms. The pinched cone conformation is stable up to at least $120^{\circ} \mathrm{C}$ in $\mathrm{C}_{2} \mathrm{D}_{2-}$ $\mathrm{Cl}_{4}$. The bis(ureido)calix[4]arenes $\mathbf{2 b}$ and $\mathbf{2 c}$ most likely form a hydrogen-bonded dimer, while bis(n-octyl(thio)ureido)calix[4]arenes $\mathbf{2 a}$ and $\mathbf{4}$ are present as monomers. A calix[4]arene functionalized with two acetamido groups (5) adopts a pinched cone conformation due to intramolecular hydrogen bonding between the two opposite acetamido groups. The pinched cone conformation is stable up to at least $145^{\circ} \mathrm{C}$. These results imply that due to hydrogen bonding in the pinched cone conformation in $\mathbf{2 a}-\mathbf{c}, \mathbf{4}$, and $\mathbf{5}$, the calix[4]arene skeleton is rigidified.

\section{Experimental Section}

All melting points are uncorrected. ${ }^{1} \mathrm{H} N M R$ and ${ }^{13} \mathrm{C} N M R$ spectra were recorded with a $250 \mathrm{MHz}$ spectrometer in $\mathrm{CDCl}_{3}$ with $\mathrm{Me}_{4} \mathrm{Si}$ as an internal standard unless stated otherwise. NOESY, ROESY, and temperature-dependent ${ }^{1} \mathrm{H}$ NMR spectra were recorded on a $400 \mathrm{MHz}$ spectrometer. The temperaturedependent experiments were performed in $\mathrm{C}_{2} \mathrm{D}_{2} \mathrm{Cl}_{4}$ with intervals of $10^{\circ} \mathrm{C}$. In the NOESY and ROESY experiments the mixing times varied between 30 and $225 \mathrm{~ms}$. For the calculation of the distances NOESY spectra were recorded with three different mixing times. FAB mass spectra were obtained using m-nitrobenzyl alcohol (NBA) as a matrix. FTIR spectra were recorded with 32 scans and a resolution of $2 \mathrm{~cm}^{-1}$. Molecular weight determinations were carried out on a vapor pressure osmometer in glass-distilled HPLC-grade $\mathrm{CHCl}_{3}$ at $29^{\circ} \mathrm{C}$ in a concentration range of $4.6-65.3 \mathrm{~g} \cdot \mathrm{kg}^{-1}$. Benzil was used as calibration standard. $\mathrm{CHCl}_{3}$ was distilled from $\mathrm{CaCl}_{2}$ and stored over molecular sieves $3 \AA$, toluene was distilled over $\mathrm{Na}$ and stored over molecular sieves $3 \AA$. All other solvents and chemicals were used without purification. Silica gel (particle size 0.040-0.063 mm, 230-240 mesh) was obtained from Merck. All reactions were carried out under an argon atmosphere. For reasons of clarity and to reduce space the name calix[4]arene was used instead of the original IUPAC name: pentacyclo[19.3.1.1 $\left.1^{3,7} \cdot 1^{9,13} \cdot 1^{15,19}\right]$ octacosa-1(25),3,5,7(28),9,11,13(27),15,17,19(26),21,23-dodecane. Before the elemental analysis the samples were dried overnight over $\mathrm{P}_{2} \mathrm{O}_{5}$ at a minimum of $75{ }^{\circ} \mathrm{C}$. The presence of solvent in the analytical samples was confirmed by ${ }^{1} \mathrm{H}$ NMR spectroscopy. 1,3-Diaminocalix[4]arene $\mathbf{1}$ was synthesized according to a literature procedure. ${ }^{11}$ The synthesis of bis(acetamido)calix[4]arene 5 was reported previously. ${ }^{13}$ Molecular Modeling was

(32) (a) Taylor, R.; Kennard, O.; Versichel, W. J . Am. Chem. Soc. 1983, 105, 5761. (b) Taylor, R.; Kennard, O.; Versichel, W. I bid. 1984 106, 244.

(33) Etter, M. C.; Urbañczyk-Lipowska, Z.; Zia-Ebrahimi, M.; Panuto, T. W. J . Am. Chem. Soc. 1990, 112, 8415. performed with $\mathrm{CHARMm}{ }^{27}$ version 22.0 as implemented in Quanta version 3.3.34 Energy minimizations were carried out (Adopted Based N ewton-Raphson) until the root mean square of the gradient was $<0.01 \mathrm{kcal} \cdot \mathrm{mol}^{-1} \cdot \AA^{-1}$. A distancedependent dielectric constant was applied. No cut-offs on the nonbonded interactions were used. Charges on atoms were calculated from point charge templates. The resulting net charges were smoothed over nonpolar carbonyl and hydrogen atoms.

5,17-Bis[N'-(R)ureido]-25,26,27,28-tetrakis[(ethoxycarbonyl)methoxy]calix[4]arene $\mathbf{2 a}-\mathbf{c}$. To a solution of 1,3diaminocalix[4]arene $\mathbf{1}(0.96 \mathrm{~g}, 1.03 \mathrm{mmol})$ in $\mathrm{CHCl}_{3}(20 \mathrm{~mL})$ was added 2 equiv of the appropriate isocyanate $(4.42 \mathrm{mmol})$, and the mixture was stirred at room temperature for $3 \mathrm{~h}$. Then $\mathrm{H}_{2} \mathrm{O}(20 \mathrm{~mL}$ ) was added, and the organic layer was separated; the crude products were purified as described below.

2a: $\mathrm{R}=\mathrm{n}$-octyl. The crude product was triturated with diisopropyl ether followed by recrystallization from $\mathrm{CHCl}_{3} /$ diisopropyl ether: yield 44\%; $\mathrm{mp} 92-94^{\circ} \mathrm{C}$; IR (KBr) $v 3366$ (NH), $1762\left(\mathrm{C}=\mathrm{O}_{\text {ester }}\right), 1653\left(\mathrm{C}=\mathrm{O}_{\text {urea }}\right) \mathrm{cm}^{-1} ;{ }^{1} \mathrm{H}$ NMR $\delta 7.01$ $(\mathrm{d}, 4 \mathrm{H}$, J $=7.1 \mathrm{~Hz}), 6.89(\mathrm{t}, 2 \mathrm{H}, \mathrm{J}=6.9 \mathrm{~Hz}), 6.1-6.0(\mathrm{br} \mathrm{s}, 2$ $\mathrm{H}), 6.02(\mathrm{~s}, 4 \mathrm{H}), 5.1-5.0(\mathrm{brt}, 2 \mathrm{H}), 4.9-4.8(\mathrm{~m}, 8 \mathrm{H}), 4.52(\mathrm{~s}$, $4 \mathrm{H}), 3.78,3.71(2 \mathrm{~s}, 8 \mathrm{H}), 3.20(\mathrm{~d}, 4 \mathrm{H}, \mathrm{J}=14.0 \mathrm{~Hz}), 3.09(\mathrm{q}$, $4 \mathrm{H}, \mathrm{J}=5.9 \mathrm{~Hz}), 1.4-1.1(\mathrm{~m}, 30 \mathrm{H}), 1.12(\mathrm{t}, 6 \mathrm{H}, \mathrm{J}=5.1 \mathrm{~Hz})$, $0.88(\mathrm{t}, 6 \mathrm{H}) ;{ }^{1} \mathrm{H}$ NMR (DMSO-d 6 ) $\delta 8.02(\mathrm{~s}, 2 \mathrm{H}), 6.90,6.47(2$ $\mathrm{s}, 8 \mathrm{H}), 5.9-5.8(\mathrm{brt}, 2 \mathrm{H}), 4.70,4.60(2 \mathrm{~s}, 8 \mathrm{H}), 4.65$ and 3.11 $(\mathrm{ABq}, 8 \mathrm{H}, \mathrm{J}=12.0 \mathrm{~Hz}), 4.15(\mathrm{q}, 8 \mathrm{H}, \mathrm{J}=7.3 \mathrm{~Hz}), 3.05(\mathrm{q}, 4$ $\mathrm{H}, \mathrm{J}=5.9 \mathrm{~Hz}), 1.4-1.1(\mathrm{~m}, 36 \mathrm{H}), 0.86(\mathrm{t}, 6 \mathrm{H}, \mathrm{J}=6.7 \mathrm{~Hz})$; ${ }^{13} \mathrm{C}$ NMR $\delta 171.0$ and $170.0(\mathrm{~s}), 157.1(\mathrm{~s}), 156.3(\mathrm{~s}), 151.8(\mathrm{~s})$, 135.7 (s), 134.5 (s), 133.1 (s), 129.4 (d), 123.1 (d), 121.6 (d), $71.3(\mathrm{t}), 70.9(\mathrm{t}), 68.3(\mathrm{t}), 51.8(\mathrm{t}), 51.4(\mathrm{t}), 40.2(\mathrm{t}), 31.9(\mathrm{t})$, $31.4(\mathrm{t}), 30.2(\mathrm{t}), 29.4(\mathrm{t}), 29.3(\mathrm{t}), 26.9(\mathrm{t}), 22.9(\mathrm{t}), 22.7(\mathrm{q})$, 14.1 (q); FAB mass spectrum, positive $\mathrm{m} / \mathrm{z} 1131.7\left([\mathrm{M}+\mathrm{Na}]^{+}\right.$, calcd 1132.3), negative $\mathrm{m} / \mathrm{z} 1108.0\left([\mathrm{M}-\mathrm{H}]^{-}\right.$, calcd 1108.3). Anal. Calcd for $\mathrm{C}_{62} \mathrm{H}_{84} \mathrm{~N}_{4} \mathrm{O}_{14} \cdot 0.5 \mathrm{H}_{2} \mathrm{O}$ : C, 66.59; $\mathrm{H}, 7.65 ; \mathrm{N}$, 5.01. Found: C, 66.59; $\mathrm{H}, 7.42 ; \mathrm{N}, 5.08$.

2b: $\mathrm{R}=$ phenyl. The crude product was triturated from $\mathrm{CHCl}_{3} /$ diisopropyl ether: yield 50\%; $\mathrm{mp} 141{ }^{\circ} \mathrm{C}$; IR $(\mathrm{KBr}) v$ $3392(\mathrm{NH}), 1734\left(\mathrm{C}=\mathrm{O}_{\text {ester }}\right), 1653\left(\mathrm{C}=\mathrm{O}_{\text {urea }}\right) \mathrm{cm}^{-1}$; ${ }^{1 \mathrm{H}} \mathrm{NMR} \delta$ $7.3-7.1(\mathrm{~m}, 10 \mathrm{H}), 6.98(\mathrm{~d}, 6 \mathrm{H}, \mathrm{J}=7.0 \mathrm{~Hz}), 6.87(\mathrm{t}, 2 \mathrm{H}, \mathrm{J}=$ $7.1 \mathrm{~Hz}), 6.63(\mathrm{~s}, 2 \mathrm{H}), 6.04(\mathrm{~s}, 4 \mathrm{H}), 4.92$ and $3.09(\mathrm{ABq}, 8 \mathrm{H}$, $\mathrm{J}=12.7 \mathrm{~Hz}), 4.95,4.47(2 \mathrm{~s}, 8 \mathrm{H}), 4.3-4.0(\mathrm{~m}, 8 \mathrm{H}), 1.3-1.1$ $(\mathrm{m}, 12 \mathrm{H}) ;{ }^{1} \mathrm{H}$ NMR $\left(D_{M S O}-\mathrm{d}_{6}\right) \delta 8.46(\mathrm{~s}, 2 \mathrm{H}), 8.28(\mathrm{~s}, 2 \mathrm{H})$, $7.35(\mathrm{~d}, 4 \mathrm{H}, \mathrm{J}=8.0 \mathrm{~Hz}), 7.22(\mathrm{t}, 4 \mathrm{H}, \mathrm{J}=7.6 \mathrm{~Hz}), 6.91(\mathrm{t}, 8$ $\mathrm{H}, \mathrm{J}=7.4 \mathrm{~Hz}), 6.56(\mathrm{~s}, 4 \mathrm{H}), 4.7-4.6(\mathrm{~m}, 8 \mathrm{H}), 4.2-4.1(\mathrm{~m}, 8$ $\mathrm{H}), 3.15(\mathrm{ABq}, 4 \mathrm{H}, \mathrm{J}=13.4 \mathrm{~Hz}), 1.22(\mathrm{t}, 12 \mathrm{H}$, J $=7.1 \mathrm{~Hz})$; ${ }^{13} \mathrm{C}$ NMR $\delta 170.6$ (s), 169.5 (s), 156.9 (s), 156.8 (s), 154.4 (s), 152.3 (s), 138.5 (s), 135.6 (d), 134.3 (s), 132.1 (d), 129.3 (d), 128.9 (d), 123.0 (d), 122.9 (d), 122.4 (d), 119.3 (s), 71.5 (t), 70.9 $(\mathrm{t}), 60.7(\mathrm{t}), 60.3(\mathrm{t}), 31.4(\mathrm{t}), 14.2(\mathrm{q}), 14.2(\mathrm{q}) ; \mathrm{FAB}$ mass spectrum, positive $\mathrm{m} / \mathrm{z} 1060.3\left(\left[\mathrm{M}+\mathrm{Na}^{+}\right.\right.$calcd 1060.1), negative $\mathrm{m} / \mathrm{z} 1035.8\left([\mathrm{M}-\mathrm{H}]^{-}\right.$calcd 1036.0). Anal. Calcd for $\mathrm{C}_{58} \mathrm{H}_{68} \mathrm{~N}_{4} \mathrm{O}_{112} \cdot \mathrm{H}_{2} \mathrm{O}$ : C, 66.03; H, 5.92; N, 5.31. F ound: $\mathrm{C}$, $66.07 ; \mathrm{H}, 5.74 ; \mathrm{N}, 5.35$.

2c: $\mathrm{R}=$ tert-butyl. The crude product was purified by column chromatography $\left(\mathrm{SiO}_{2} ; \mathrm{CH}_{2} \mathrm{Cl}_{2}:\right.$ EtOAC $\left.=1: 1\right)$ : yield

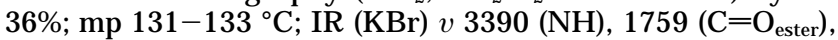
$1653\left(\mathrm{C}=\mathrm{O}_{\text {urea }}\right) \mathrm{cm}^{-1}$; ${ }^{1} \mathrm{H}$ NMR $\delta 6.96(\mathrm{~d}, 4 \mathrm{H}, \mathrm{J}=7.2 \mathrm{~Hz}), 6.81$ $(\mathrm{t}, 2 \mathrm{H}, \mathrm{J}=7.4 \mathrm{~Hz}), 6.27(\mathrm{~s}, 2 \mathrm{H}), 6.01(\mathrm{~s}, 4 \mathrm{H}), 5.09(\mathrm{~s}, 2 \mathrm{H})$, 4.82 and $3.21(\mathrm{ABq}, 8 \mathrm{H}, \mathrm{J}=14.2 \mathrm{~Hz}), 4.80,4.52(2 \mathrm{~s}, 8 \mathrm{H})$, 4.3-4.1 (m, $8 \mathrm{H}), 1.3-1.2(\mathrm{~m}, 48 \mathrm{H}) ;{ }^{1} \mathrm{H}$ NMR (DMSO- $\left.\mathrm{d}_{6}\right) \delta$ $7.95(\mathrm{~s}, 2 \mathrm{H}), 6.94(\mathrm{~s}, 4 \mathrm{H}), 6.40(\mathrm{~s}, 6 \mathrm{H}), 5.81(\mathrm{~s}, 2 \mathrm{H}), 4.73$, $4.54(2 \mathrm{~s}, 8 \mathrm{H}), 4.2-4.0(\mathrm{~m}, 8 \mathrm{H}), 1.3-1.1(\mathrm{~m}, 30 \mathrm{H}) ;{ }^{13} \mathrm{C} \mathrm{NMR}$ $\delta 170.4$ (s), 169.8 (s), 156.5 (s), 156.6 (s), 152.2 (s), 135.2 (s), $134.7(\mathrm{~s}), 133.5(\mathrm{~s}), 129.0$ (d), 123.0 (d), 122.2 (d), $71.4(\mathrm{t}), 71.1$ $(\mathrm{t}), 60.6(\mathrm{t}), 60.4(\mathrm{t}), 31.4(\mathrm{t}), 29.7(\mathrm{~s}), 29.5(\mathrm{q}), 14.2(\mathrm{q}) ; \mathrm{FAB}$ mass spectrum, positive $\mathrm{m} / \mathrm{z} 997.2\left([\mathrm{M}]^{+}\right.$, calcd 997.1), 1019.6 $\left(\left[\mathrm{M}+\mathrm{Na}^{+}\right.\right.$, calcd 1020.1); negative $\mathrm{m} / \mathrm{z} 994.9\left([\mathrm{M}-2 \mathrm{H}]^{-}\right.$, calcd 995.1). Anal. Calcd for $\mathrm{C}_{54} \mathrm{H}_{68} \mathrm{~N}_{4} \mathrm{O}_{14} \cdot 0.5 \mathrm{H}_{2} \mathrm{O}$ : C, 64.47; $\mathrm{H}, 6.90 ; \mathrm{N}, 5.57$. Found: C, 64.41; H, 6.49; N, 5.48.

5,17-Diisothiocyanato-25,26,27,28-tetrakis[(ethoxycarbonyl)methoxy]calix[4]arene (3). 1,3-Diaminocalix[4]arene $1(0.66 \mathrm{~g}, 0.83 \mathrm{mmol})$ was dissolved in toluene $(50 \mathrm{~mL})$.

(34) Quanta was purchased from Molecular Simulations, Inc., Burlington, MA. 
Thiophosgene $(0.31 \mathrm{~mL}, 4.13 \mathrm{mmol})^{35}$ was added followed by $\mathrm{Et}_{3} \mathrm{~N}(0.53 \mathrm{~mL}, 4.13 \mathrm{mmol})$, and the mixture was refluxed for $3 \mathrm{~h}$. The reaction mixture was evaporated thoroughly and the residue was taken up in $\mathrm{CH}_{2} \mathrm{Cl}_{2}(100 \mathrm{~mL})$, washed with $\mathrm{H}_{2} \mathrm{O}$ $(2 \times 50 \mathrm{~mL})$, and dried with $\mathrm{MgSO}_{4}$. After filtration and evaporation of the solvent the crude product was purified by column chromatography $\left(\mathrm{SiO}_{2} ; \mathrm{CH}_{2} \mathrm{Cl}_{2}: \mathrm{MeOH}=99: 1\right)$ to give 3 as a brown oil: yield 89\%; IR $\left(\mathrm{CDCl}_{3}\right) v 2131$ (NCS) $\mathrm{cm}^{-1}$; ${ }^{1} \mathrm{H}$ NMR $\delta 6.68(\mathrm{t}, 6 \mathrm{H}, \mathrm{J}=7.2 \mathrm{~Hz}), 6.50(\mathrm{~s}, 4 \mathrm{H}), 4.87$ and $3.17(\mathrm{ABq}, 8 \mathrm{H}, \mathrm{J}=15.0 \mathrm{~Hz}), 4.72$ and $4.68(2 \mathrm{~s}, 8 \mathrm{H}), 4.3-4.2$ $(\mathrm{m}, 8 \mathrm{H}), 1.3-1.2(\mathrm{~m}, 12 \mathrm{H}) ;{ }^{13} \mathrm{C} N M R \delta 169.7(\mathrm{~s}), 167.3(\mathrm{~s})$, 156.7 (s), 152.4 (s), 133.7 (s), 131.3 (s), 128.8 (s), 126.4 (d), 125.5 $(\mathrm{s}), 123.5(\mathrm{~s}, \mathrm{NCS}), 123.0(\mathrm{~d}), 71.2(\mathrm{t}), 68.3(\mathrm{t}), 60.6(\mathrm{t}), 58.1(\mathrm{t})$, $31.2(\mathrm{t}), 14.1(\mathrm{q}), 11.7(\mathrm{q}) ; \mathrm{FAB}$ mass spectrum, positive $\mathrm{m} / \mathrm{z}$ $881.9\left(\mathrm{M}^{+}\right.$, calcd 882.9), $905.0\left([\mathrm{M}+\mathrm{Na}]^{+}\right.$, calcd 905.2).

5,17-Bis(N'-n-octylthioureido)-25,26,27,28-tetrakis[(ethoxycarbonyl)methoxy]calix[4]arene (4) was prepared as described for $\mathbf{2 a}$-c starting from 1,3-diisothiocyanatocalix[4]arene 3 using 2 equiv of $n$-octylamine: yield $68 \%$; $\mathrm{mp} 149^{\circ} \mathrm{C}$; IR $(\mathrm{KBr}) v 3290(\mathrm{NH}) \mathrm{cm}^{-1}$; ${ }^{1} \mathrm{H}$ NMR $\delta 7.0-6.9(\mathrm{~m}, 8 \mathrm{H})$,

(35) A small excess of thiophosgene was used to prevent the formation of $N, N^{\prime}$-disubstituted thioureas. ${ }^{12}$
6.6-6.5 (br t, $2 \mathrm{H}), 6.04(\mathrm{~s}, 4 \mathrm{H}), 4.89$ and $3.23(\mathrm{ABq}, 8 \mathrm{H}, \mathrm{J}=$ $13.9 \mathrm{~Hz}), 4.83,4.57(2 \mathrm{~s}, 8 \mathrm{H}), 4.3-4.1(\mathrm{~m}, 8 \mathrm{H}), 3.49(\mathrm{q}, 4 \mathrm{H}$, $\mathrm{J}=5.7 \mathrm{~Hz}), 1.6-1.5(\mathrm{~m}, 4 \mathrm{H}), 1.3-1.2(\mathrm{~m}, 36 \mathrm{H}), 0.88(\mathrm{t}, 12$ $\mathrm{H}, \mathrm{J}=6.6 \mathrm{~Hz}$ ); ${ }^{13} \mathrm{C}$ NMR $\delta 180.5$ (s), 170.4 (s), 169.5 (s), 156.7 (s), $153.6(\mathrm{~s}), 135.7$ (d), $135.1(\mathrm{~s}), 131.9(\mathrm{~d}), 129.4(\mathrm{~d}), 124.0(\mathrm{~s})$, $123.5(\mathrm{~s}), 71.6(\mathrm{t}), 71.0(\mathrm{~s}), 60.9(\mathrm{t}), 60.4(\mathrm{t}), 45.3(\mathrm{t}), 31.8(\mathrm{t})$, $31.5(\mathrm{t}), 29.3(\mathrm{t}), 29.3(\mathrm{t}), 28.9(\mathrm{t}), 27.0(\mathrm{t}), 22.7(\mathrm{t}), 14.2(\mathrm{q})$, 14.1 (q); FAB mass spectum, positive $\mathrm{m} / \mathrm{z} 1141.8\left(\mathrm{M}^{+}\right.$, cal cd 1141.4), negative $\mathrm{m} / \mathrm{z} 1139.2\left([\mathrm{M}-2 \mathrm{H}]^{-}\right.$, calcd 1139.4). Anal. Calcd for $\mathrm{C}_{62} \mathrm{H}_{84} \mathrm{~N}_{4} \mathrm{O}_{12} \mathrm{~S}_{2}$ : C, 65.24; $\mathrm{H}, 7.40 ; \mathrm{N}, 4.91$. Found: C, 64.86; H, 7.40; N, 4.94 .

Acknowledgment. The research described in this paper was supported by the Netherlands Foundation for Chemical Research (SON) with the financial aid from the Netherlands Organization for Scientific Research (NWO) and by AKZO-Nobel Central Research bv. We also acknowledge A. M. Montanaro-Christenhusz for performing the elemental analyses, T. W. Stevens for recording the mass spectra, and $A$. Schothuis for the assistance in the NMR experiments.

J 09600262 